Article

\title{
Suitability of Recombinant Lipase Immobilised on Functionalised Magnetic Nanoparticles for Fish Oil Hydrolysis
}

\author{
Madan L Verma ${ }^{1}$, Nalam M Rao ${ }^{2}$, Takuya Tsuzuki ${ }^{3}{ }^{\circledR}$, Colin J Barrow ${ }^{1}$ and Munish Puri ${ }^{1,4, *}$ \\ 1 Centre for Chemistry and Biotechnology, Deakin University, Waurn Ponds, Geelong 3216, VIC, Australia; \\ madanverma@gmail.com (M.L.V.); cbarrow@deakin.edu.au (C.J.B.) \\ 2 Centre for Cellular and Molecular Biology, Council of Scientific and Industrial Research, Hyderabad 500007, \\ India; madhu@ccmb.res.in \\ 3 Research School of Engineering, Australian National University, Canberra 2601, ACT, Australia; \\ Takuya.tsuzuki@anu.edu.au \\ 4 Centre for Marine Bioproducts Development, College of Medicine and Public Health, Flinders University, \\ Bedford Park SA, Adelaide 5042, SA, Australia \\ * Correspondence: munish.puri@deakin.edu.au; Tel.: +61-872-218-573
}

Received: 31 March 2019; Accepted: 25 April 2019; Published: 3 May 2019

\begin{abstract}
Recombinant Bacillus subtilis lipase was immobilised on magnetic nanoparticles by a facile covalent method and applied to fish oil hydrolysis. High loading of enzyme to the functionalised nanoparticle was achieved with a protein binding efficiency of $95 \%$. Structural changes of the confined enzyme on the surface of the nanoparticles was investigated using transmission electron microscopy and spectroscopic techniques (attenuated total reflectance-Fourier transform infrared and circular dichroism). The biocatalytic potential of immobilised lipase was compared with that of free enzyme and biochemically characterised with respect to different parameters such as $\mathrm{pH}$, temperature, substrate concentrations and substrate specificity. The thermal stability of functionalised nanoparticle bound enzyme was doubled that of free enzyme. Immobilised lipase retained more than $50 \%$ of its initial biocatalytic activity after recyclability for twenty cycles. The ability to the immobilised thermostable lipase to concentrate omega-3 fatty acids from fish oil was investigated. Using synthetic substrate, the immobilised enzyme showed 1.5 times higher selectivity for docosahexaenoic acid (DHA), and retained the same degree of selectivity for eicosapentaenoic acid (EPA), when compared to the free enzyme.
\end{abstract}

Keywords: magnetic; covalent immobilisation; recombinant enzyme; structure characterisation; fish oil; omega-3 fatty acids

\section{Introduction}

Enzymes have been used as food additives or in processing raw material in food biotechnology for many years. Enzymes labelled as GRAS (Generally Recognised As Safe), are regulated for use in the US food industry as either ingredients or processing aids [1,2]. However, the number of these is limited and so there are efforts to discover novel enzymes and optimisation of their inherent properties such as stability, reaction rate and specificity, to enable the development of new green industrial processing methods. Uses of enzymes in food processing strictly follows green chemistry approaches, including avoiding use of costly harsh chemicals in various food processing activities [3,4]. Exploring novel robust enzymes sourced from recombinant/wild microbial strains can provide new industrially useful catalysts for food or industrial processes. 
In the food industry, microbial lipases are considered important enzymes that are extensively employed for lipids-enriched foods processes [5]. Lipases can catalyse the hydrolysis/synthesis of long chain esters at the interface of biphasic media [6]. The stereo-, regio- and enantio-specificity of lipase-catalysed reactions are important for a plethora of biotechnological applications in different sectors such as food, dairy and pharmaceutical [7]. Recently, lipases have been used in marine oil processing for concentrating omega-3 polyunsaturated fatty acids (n-3 PUFAs) to produce omega-3 concentrates for nutritional supplement use. Biotransformation of docosahexaenoic acid (DHA) and eicosapentaenoic acid (EPA) enriched marine oils requires high selectivity and mild reaction conditions, due to the inherent instability of these highly unsaturated systems, and so enzyme-mediated processes are preferable for the production of PUFA concentrates for nutraceuticals and pharmaceutical use [8].

However, enzymes are fragile and work within very specific temperatures and environments that mimic their in vivo milieu. Enzymatic processes are not industrially favourable due to cost and the short catalytic lifespan of many enzymes [9]. To overcome these issues, enzyme immobilisation provides a pragmatic solution to both improve enzyme stability and enable reusability [10]. The use of novel immobilisation technologies for these enzymatic processes can develop recyclable enzymes, thereby decreasing costs per cycle [11]. Enzymes are immobilised to the solid supports by well-established immobilisation methods. Such methods can be chemical free or chemical treated and lead to either physical adsorption or covalent binding for immobilisation [12,13]]. Adsorption methods are easy to perform but prone to $\mathrm{pH}$ changes. Protein leaching is a serious problem in this method. To overcome this issue, covalent methods can be employed using suitable cross-linkers [14].

Recently, nanotechnology has provided alternative materials for enzyme immobilisation, introducing nanoscale materials [15-17]. Various nanomaterials have been used in food related industrial processes [18]. Advantageous properties of nanomaterial over the bulk material include larger surface area for higher biomolecule loading, and also potentially high activity and stability of the nanomaterial immobilised biocatalyst [11]. Amongst various nanostructured forms, magnetic nanoparticles are particularly significant as novel supports due to their ease of removal using magnetic field methods that bypass the need for sophisticated high-speed refrigerated centrifugation instrumentation [12]. Additional benefit of magnetic nanoparticle carriers includes biocompatibility, chemical stability, non-toxicity and superparamagnetic properties that can further improved the cost effectiveness of enzyme assisted processes [19]. Robust nanostructured material can be modified with surface functionalisation agents using established enzyme immobilisation methods [20].

This present study was focused on developing a simple method to immobilise recombinant lipase on magnetic nanoparticles for fish oil hydrolysis to concentrate omega-3 fatty acid. Magnetic nanoparticles were synthesised through a hydrothermal method and zinc doping was done to achieve high magnetisation for efficient recovery. Recombinant lipase sourced from Bacillus subtilis was selected as a model protein for enzyme immobilisation. A post-immobilisation modification of the enzyme was studied with microscopy (transmission electron microscopy, TEM), and spectroscopy (attenuated total reflectance-Fourier transform infrared (ATR-FTIR) and Circular dichroism (CD). The biocatalytic potential of immobilised enzyme as a function of different reaction conditions $(\mathrm{pH}$, temperature, substrate selectivity, thermal stability and recyclability studies) was also investigated. Immobilised lipase was evaluated for concentration of the omega-3 fatty acids EPA and DHA from anchovy fish oil. To the best of our knowledge, this is the first report of recombinant Bacillus subtilis lipase 6B immobilisation on zinc doped magnetic nanoparticle for structural characterisation and applications in fish oil hydrolysis and omega-3 concentration.

\section{Results and Discussion}

\subsection{Characterisation of Zinc Doped Magnetic Nanoparticle}

XRD studies revealed the ferrite crystal phases of the nanoparticles. The saturation magnetisation of doped magnetic nanoparticles $(109 \mathrm{emu} / \mathrm{g}$ ) was considerably higher than that of undoped nanoparticles 
$(<60 \mathrm{emu} / \mathrm{g}$ ) at $50 \mathrm{kOe}$ (Figure S4. The magnetic hysteresis loop of the doped nanoparticles showed a zero coercivity, indicative of a superparamagnetic nature, that enable the quick enzyme separation via a magnet as well as high surface area of the nanoparticle being stable dispersal for higher enzyme loading without a magnet [12]. TEM images showed that the particles have diameter around $25 \mathrm{~nm}$ (Figure 1a).
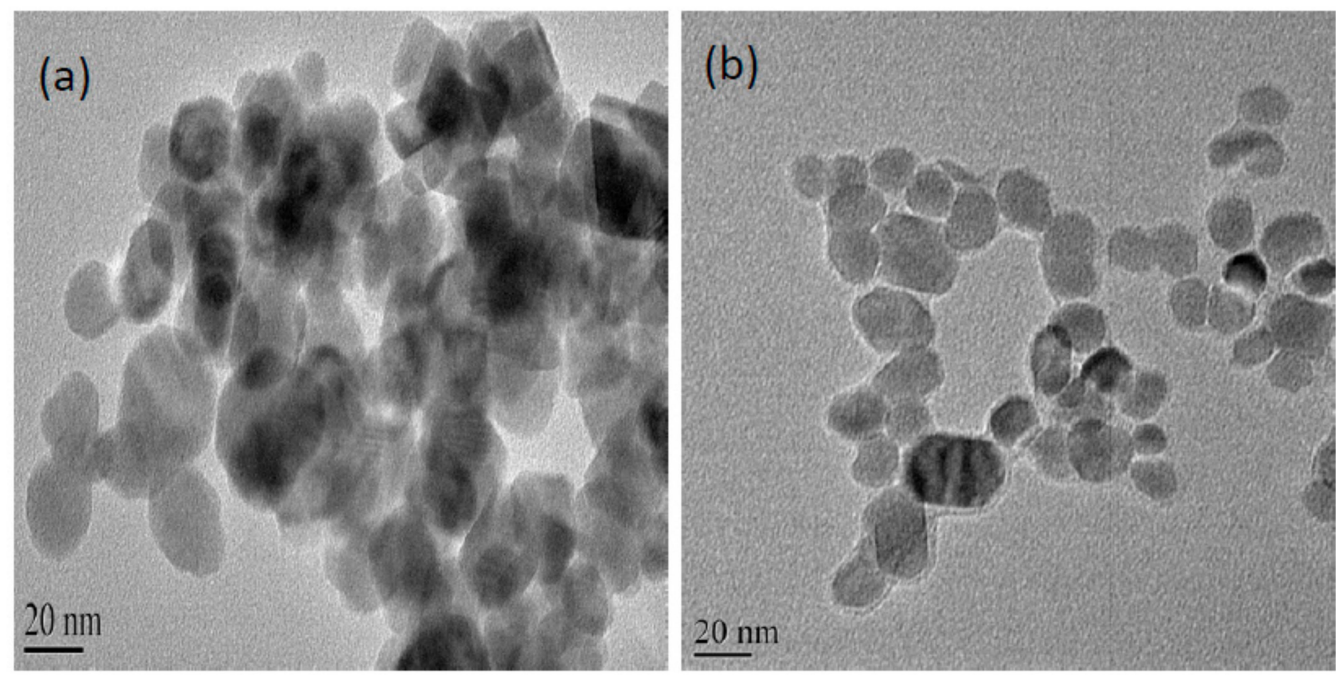

Figure 1. TEM images of functionalised magnetic nanoparticle (a) and nanoparticle immobilised lipase (b). Nanoparticle immobilised lipase (b) showed the uniform coating of protein as compared to the pristine nanoparticle $(\mathbf{a})$.

\subsection{Enzyme Immobilisation Kinetics}

Magnetic nanoparticles possesses surface hydroxyl groups which can be exploited for enzyme binding via glutaraldehyde activation [12]. Protein loading on the nanoparticle was $0.6 \mathrm{mg} / \mathrm{mg}$ and activity recovery was 70\% (Supplementary Figure S2). Functionalised magnetic nanoparticle immobilised Serratia marcescens lipase achieved $62 \%$ activity recovery and protein loading was $32 \mathrm{mg}$ protein/g [21]. A recent study reported similar observations of high protein loading using magnetic nanoparticles [12]. In a recent study, graphene-magnetic nanocomposite immobilized Candida rugosa lipase demonstrated high protein loading and achieved $65 \%$ activity recovery [9]. The high lipase loading indicates that the functionalised magnetic nanoparticle is a good support material for immobilisation of this lipase.

\subsection{Structural Characterisation of Immobilised Enzyme}

TEM was employed to study the size and morphology of the functionalised nanoparticles. Figure 1 shows the morphology of pristine nanoparticle and enzyme immobilised nanoparticle using TEM. Simultaneous visualisation of free and enzyme bound magnetic nanoparticle under TEM with the same resolution was recorded with negative staining, where electron dense material (phosphotungstic acid) was introduced onto the nanomaterial to enhance contrast. The enzymes appeared as halos surrounding the nanoparticles confirming the coating of enzymes on the nanoparticles. The nanoparticle size ranged from $20 \mathrm{~nm}$ to $50 \mathrm{~nm}$ with near-spherical shapes. The nanoparticles show some aggregation. A similar TEM study with negative staining was also used for studying bio-functionalised gold nanoparticle as it enabled the protein surrounding the nanoparticles to be imaged [22].

The Fourier transform infrared spectrum of freeze-dried free and enzyme immobilised magnetic nanoparticle was taken in absorbance mode. ATR-FTIR spectra of immobilised enzyme are shown in Figure 2. The FTIR absorption positions, particularly in the amide regions (I and II), confirms the backbone conformation of protein [23]. The absorption peaks appearing at $1630 \mathrm{~cm}^{-1}$ (amide I band) and $1545 \mathrm{~cm}^{-1}$ (amide II band) of the FTIR spectra confirmed the amide group of recombinant lipases. 
The characteristic bands of the protein at $1639 \mathrm{~cm}^{-1}$ (amide I band) and $1522 \mathrm{~cm}^{-1}$ (the amide II band), present in zinc doped magnetic nanoparticle immobilised lipase, therefore, confirming the binding of enzyme onto the surface of magnetic nanoparticles. Additionally, the Fe-O stretching vibrations of pristine magnetic nanoparticles represented absorption peak at $531 \mathrm{~cm}^{-1}$ [24], which were also present in enzyme-bound magnetic nanoparticle with a slight shift to large wavenumber $536 \mathrm{~cm}^{-1}$.
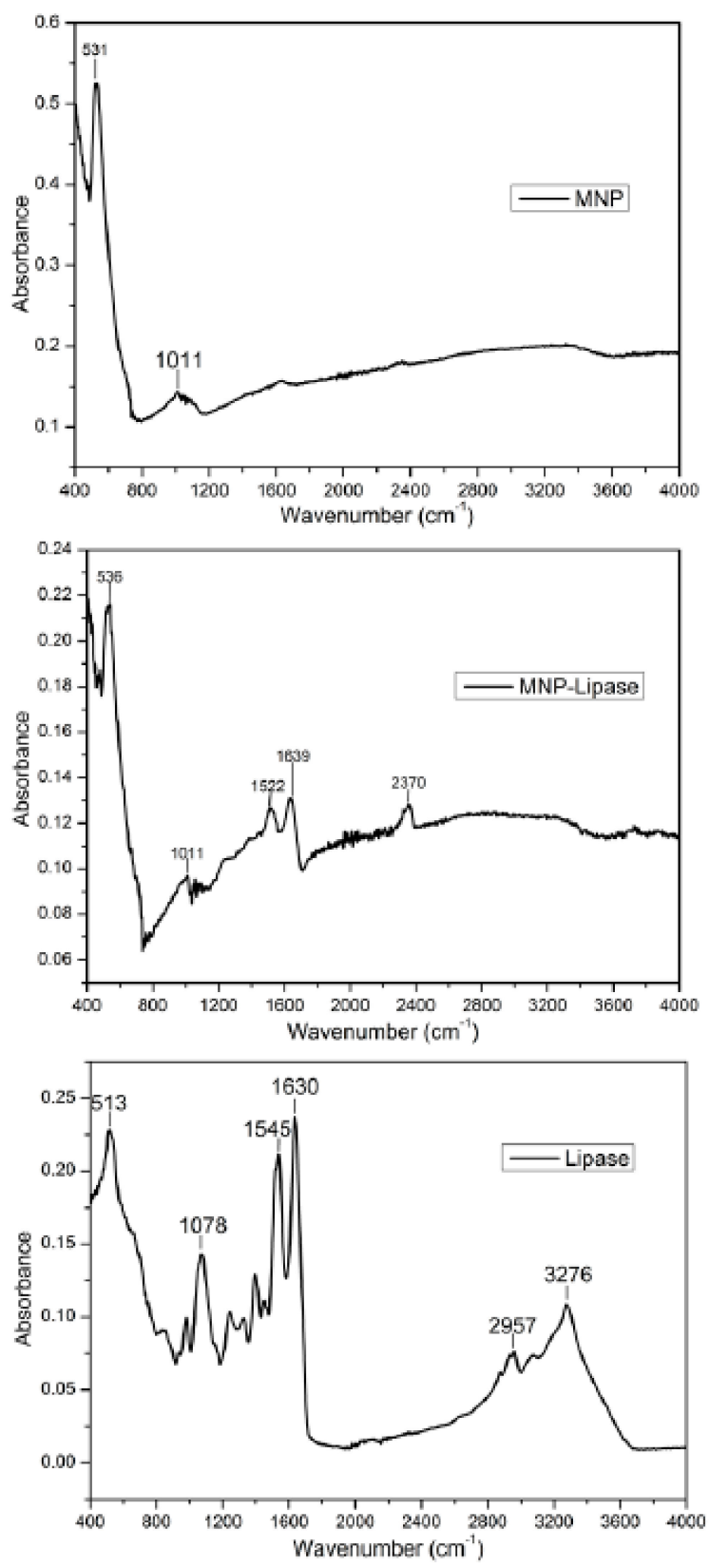

Figure 2. FTIR spectra of functionalised magnetic nanoparticle (MNP), nanoparticle immobilised lipase (MNP-Lipase) and free lipase.

CD spectroscopy is employed to track the secondary structure changes of protein [25]. The changes in the secondary structure of the enzyme after covalent binding on the surface of zinc doped magnetic nanoparticles was investigated by CD spectroscopy. The structural changes of the magnetic nanoparticle immobilised lipase were compared to the free enzyme through CD spectra analysis using the CD Pro software package (CONTIN) (Figure 3). The amount of protein secondary structure, $\alpha$-helix and $\beta$-sheet in nanoparticle bound enzyme, was slightly altered from the native enzyme, whereas turn remained 
unaltered (Table 1). Nanoparticle bound enzyme retained $84 \%$ of native $\alpha$-helix content. The unaltered $\alpha$-helix content of the magnetic nanoparticle immobilised enzyme preserved the secondary structure important for high enzyme activity [26]. Thermomyces lanuginosus lipase retained $80 \%$ of native $\alpha$-helix content after carbon nanomaterial immobilisation [13]. These studies support the use of the nanocarriers for enzyme immobilisation where changes in secondary structure are only slightly altered, with immobilisation providing higher operational stability and higher retention activity for the immobilised biocatalyst.

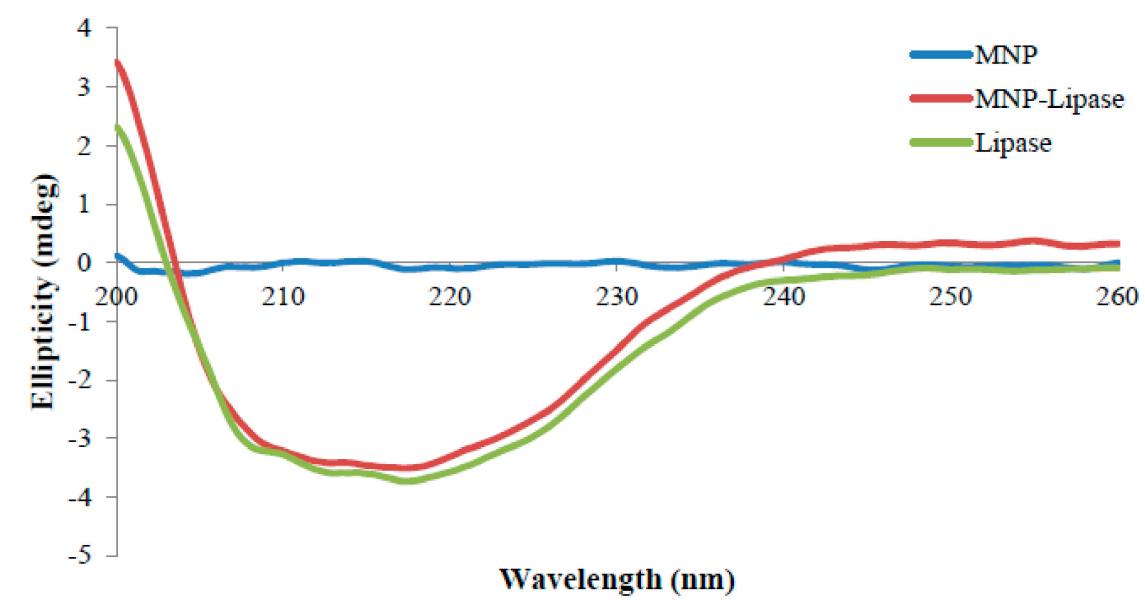

Figure 3. CD spectrum of functionalised magnetic nanoparticle (MNP), nanoparticle immobilised lipase (MNP-Lipase) and free lipase. Footnote: CD spectra of the functionalised magnetic nanoparticle (MNP), magnetic nanoparticle immobilised lipase (MNP-Lipase), and native lipase, in which the amount of the native lipase used was equivalent to that of the lipase immobilised on nanoparticle. As shown, magnetic nanoparticles have no contribution to the spectrum of the MNP-Lipase. In the measurement of the CD spectrum of the conjugates, the CD spectrum of functionalised magnetic nanoparticle was recorded as a control. CDPro software package (CONTIN) was used to analyse the protein CD spectra for determining the secondary structure fractions. From the mean residue ellipticity at $222 \mathrm{~nm}$, we know that the lipase attached to nanoparticle retains about $84 \%$ of its native $\alpha$-helix content. The observation of CD spectrum is further supplemented with the Table 1 data where the proportions of each type of secondary structure in the free and immobilised form is provided.

Table 1. Fractions of each type of secondary structure in lipase covalently immobilised to functionalised nanoparticle.

\begin{tabular}{ccccccc}
\hline Structure & H(r) & H(d) & S(r) & S(d) & Trn & Unrd \\
\hline Native enzyme & 0.272 & 0.143 & 0.038 & 0.057 & 0.197 & 0.293 \\
Immobilised enzyme & 0.228 & 0.157 & 0.027 & 0.075 & 0.197 & 0.315 \\
\hline
\end{tabular}

Abbreviations: $\mathrm{H}(\mathrm{r})$, regular $\alpha$-helix; $\mathrm{H}(\mathrm{d})$, distorted $\alpha$-helix; $\mathrm{S}(\mathrm{r})$, regular $\beta$ sheet; $\mathrm{s}(\mathrm{d})$, distorted $\beta$ sheet; Trn, Turn; Unrd, unordered. All experiments in this study were carried out in triplicate with standard deviation below $5 \%$.

\subsection{Biochemical Characterisation of the Immobilised and Free Lipase}

\subsubsection{Optimal $\mathrm{pH}$ of the Immobilised and Free Lipase}

The immobilised and free lipase exhibited optimum $\mathrm{pH}$ at $\mathrm{pH} 8.5$ (Figure 4A). The immobilised enzyme retained $90-100 \%$ activity, while the free enzyme retained $85-100 \%$ activity in the narrow $\mathrm{pH}$ range of 8.0-9.0. The immobilised enzyme showed higher biocatalytic potential than the free enzyme at higher $\mathrm{pH}$ values. The $\mathrm{pH}$ behaviour of immobilised lipase sourced from Candida antartica remained unaltered and it was 7.0 [22]. A recent study also reported no changes in pH optima after enzyme immobilisation on functionalised carbon nanomaterials [13]. 


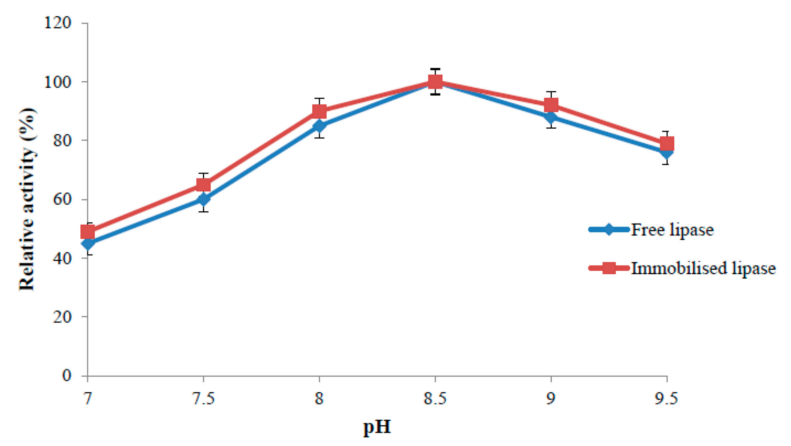

(B)

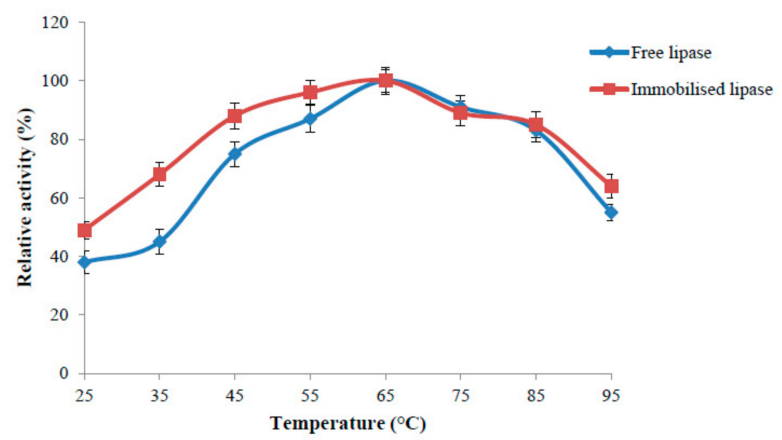

(C)

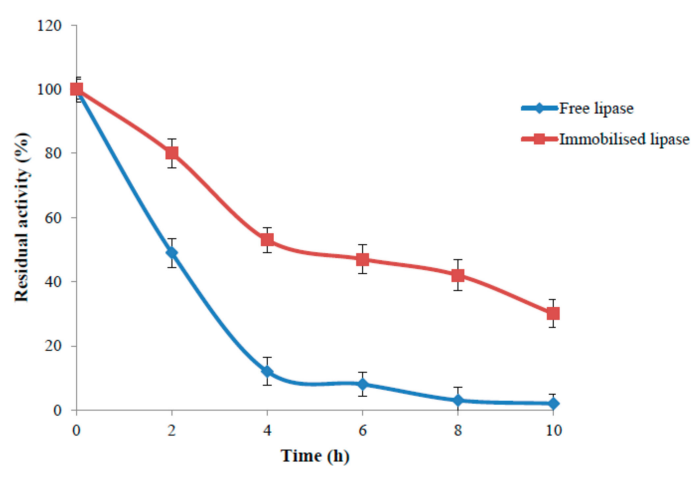

(D)

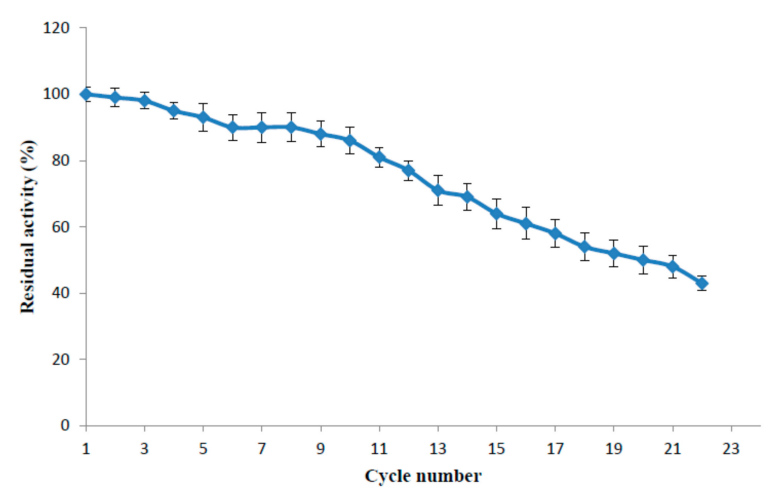

Figure 4. Catalytic activity of immobilised and free recombinant lipase as a function of $\mathrm{pH}(\mathrm{A})$, temperature (B), thermal stability $(\mathbf{C})$ and reusability $(\mathbf{D})$. The values are given as the mean of three experiments \pm standard deviation. 


\subsubsection{Optimal Temperature and Thermal Stability of the Immobilised and Free Enzyme}

The immobilised and free enzyme showed optimum temperature at $65^{\circ} \mathrm{C}$ (Figure $4 \mathrm{~B}$ ). Nanoparticle bound enzyme was more stable in the broader temperature range from $25-65^{\circ} \mathrm{C}$. Nanoparticle bound enzyme and free enzyme retained $85 \%$ and $75 \%$ of its activity, respectively, in the temperature range $45-85{ }^{\circ} \mathrm{C}$. Immobilised enzyme also retained $10 \%$ more activity as compared to free enzyme at selected high temperature $\left(95^{\circ} \mathrm{C}\right)$. However, at low temperature of $25^{\circ} \mathrm{C}$, free enzyme activity was quite low as it retained $40 \%$ of its optimum activity while immobilized enzyme retaining the $50 \%$ of the original activity. Magnetic nanoparticle immobilised Candida rugosa lipase and free enzyme exhibited the same optimal temperature at $37^{\circ} \mathrm{C}$ [27].

Robust zinc doped magnetic nanoparticle immobilised enzyme was selected to study thermal inactivation at higher temperature $\left(85^{\circ} \mathrm{C}\right)$. Free enzyme lost half its activity in the first two hours of incubation while immobilised enzyme retained $50 \%$ residual activity up to $4 \mathrm{~h}$ and $30 \%$ up to $10 \mathrm{~h}$ of incubation (Figure 4C). Thermal stability of silica-coated magnetic nanoparticle immobilised lipase was enhanced at the various reaction conditions; it was higher than the commercial lipase Novozym 435 [28]. Improved thermal stability of an enzyme is a common outcome of the immobilisation process. Nano-immobilisation technology can protect enzymes from protein unfolding and denaturation by inducing covalent bond between the support and fragile enzyme to minimise conformation rigidity as well as thermal vibrations [29].

\subsubsection{Reusability Study of the Maganetic Nanoparticle Immobilised Enzyme}

Due to ease of magnetic separation, recyclable biocatalyst was reused twenty cycles for the hydrolysis of long chain synthetic $p$ NPP esters at $65^{\circ} \mathrm{C}$ (Figure 4D). Recyclable biocatalyst demonstrated stability of the biocatalytic potential by retaining higher residual activity $(\geq 80 \%)$ up to the 11 th recycle, and retained residual activity ( $\geq 50 \%$ ) up to 20 cycles (Figure $4 \mathrm{D}$ ). Lipase immobilised on magnetic nanoparticle retained activity above $65 \%$ after seven reuse cycles at $35{ }^{\circ} \mathrm{C}$ [27] while functionalised nanoparticle immobilised Serratia marcescens lipase retained $60 \%$ activity after eleven times reuse at $30^{\circ} \mathrm{C}$ [21]. Carbon nanomaterial immobilised lipase B of Candida antarctica also retained higher activity $(\geq 50 \%)$ up to five reuse cycles at $60{ }^{\circ} \mathrm{C}$ [20]. Magnetic nanoparticle immobilised lipase sourced from Thermomyces lanuginosus retained $82 \%$ relative hydrolysis after the six reuse cycles [30]. Superior biocatalyst recyclability was reported due to nanoparticle-enzyme covalent binding and efficient magnetic separation of superparamagnetic nanoparticle without any mechanical shearing, thus presenting a cost-effective method with potential use for economically immobilised biocatalyst processes.

\subsubsection{Kinetics Study of Immobilised and Free Lipase Using Substrate (pNPP)}

Enzyme kinetics of immobilised and free lipase were investigated under standard assay conditions. Michaelis-Menten kinetic study for immobilised and free enzyme was done by measuring initial reactions rates with different substrate concentrations (Table 2). $K_{M}$ value of the nanoparticle immobilised lipase $(14.7 \mathrm{mM})$ was slightly altered from the free enzyme $(12.5 \mathrm{mM}) . V_{\max }$ value of immobilised and free enzyme was $2.1 \mathrm{U} / \mathrm{mg}$ and $3.3 \mathrm{U} / \mathrm{mg}$. $K_{M}$ values of free enzyme was slightly altered after enzyme immobilisation [31]. $K_{M}$ value of free enzyme $(0.8 \mathrm{mM})$ was altered after T. lanuginosus lipase immobilised on hydrophilic carrier $(1.5 \mathrm{mM})$. Recently, silica-coated magnetic nanoparticle immobilized lipase exhibited alteration in $K_{M}$ value from $2.3 \mathrm{mM}$ to $3.2 \mathrm{mM}$ [28]. These small changes in enzyme kinetic values indicated minuscule changes in the substrate affinity of enzyme due to restricted assess of substrate to the active site of the nanoparticle bound enzyme [7]. 
Table 2. Kinetics parameters of immobilised and free lipase using $p$-NPP substrate. All experiments in this study were carried out in triplicate with standard deviation below $5 \%$.

\begin{tabular}{ccc}
\hline Kinetic Parameters & Free Lipase & Immobilised Lipase \\
\hline$K_{M}(\mathrm{mM})$ & 12.5 & 14.7 \\
$V_{\max }(\mathrm{U} / \mathrm{mg})$ & 3.3 & 2.1 \\
\hline
\end{tabular}

Footnote: Initial rates were estimated by pNPP hydrolysis. Reaction mixtures contained 2-40 mM p-NPP, free and immobilised lipase $(2 \mathrm{U})$, in $2.9 \mathrm{~mL}$ in $50 \mathrm{mM}$ Tris buffer $\left(\mathrm{pH} 8.5,65^{\circ} \mathrm{C}\right)$. Kinetic parameters were calculated from GraphPad software (Graphpad Software, Inc., San Diego, CA, USA version 6.0) using non-linear regression fitting of the Michaelis-Menten equation. All experiments in this study were carried out in triplicate with standard deviation below $5 \%$.

\subsubsection{Substrate Selectivity of Immobilised and Free Enzyme}

Selectivity property of lipases is exploited to discover novel applications of fatty acids in marine fat and oil modification [32]. Nanoparticle immobilised and free enzyme did not show any specific trend toward different acyl chain length of synthetic substrates with a varying degree of unsaturation (Figure 5). Immobilised enzyme showed higher affinity for short chain fatty acid (C8:0, C10:0) and long chain fatty acid (C16:0, C18:1n9, C18:2n6, C22:6n3) than free enzyme. Immobilised lipase showed substrate selectivity in the following order; $\mathrm{C} 8: 0>\mathrm{C} 16: 1 \mathrm{n} 7>\mathrm{C} 14: 0>\mathrm{C} 18: 3 \mathrm{n} 3>\mathrm{C} 18: 1 \mathrm{n} 9>\mathrm{C} 10: 0=$ $\mathrm{C} 12: 0>\mathrm{C} 22: 6 \mathrm{n} 3(\mathrm{DHA})>\mathrm{C} 20: 5 \mathrm{n} 3(\mathrm{EPA})>\mathrm{C} 18: 2 \mathrm{n} 6>\mathrm{C} 16: 0>\mathrm{C} 18: 0$. Free lipase showed the substrate selectivity in following order; $\mathrm{C} 18: 3 \mathrm{n} 3>\mathrm{C} 8: 0=\mathrm{C} 12: 0>\mathrm{C} 14: 0>\mathrm{C} 18: 1 \mathrm{n} 9>\mathrm{C} 20: 5 \mathrm{n} 3(\mathrm{EPA})>\mathrm{C} 10: 0>$ $\mathrm{C} 16: 0>\mathrm{C} 16: 1 \mathrm{n} 7=\mathrm{C} 18: 2 \mathrm{n} 6>\mathrm{C} 18: 0>\mathrm{C} 22: 6 \mathrm{n} 3$ (DHA). Therefore, there were some selectivity differences between free and immobilised lipases, although these were relatively minor. Immobilised enzyme showed 1.5 times higher activity from free enzyme towards DHA, while retaining almost the same activity for EPA. Thus, immobilised lipase was more active for the hydrolysis of DHA than the free enzyme, at least with synthetic substrate. Carbon nanotube immobilised T. lanuginosus lipase showed improvement in the hydrolysis of fish oil with respect to DHA contents and it was 1.6-fold higher than the initial content of DHA fish oil [33]. Recently, modified chitosan support with different alkyl chains (C4, C8, C12) was employed for Rhizomucor miehei lipase immobilisation with application in fish (menhaden) oil hydrolysis, where modified chitosan with dodecyl alkyl chains (C12) exhibited higher selectivity for DHA [34]. The broad substrate specificity of immobilised and free lipase is useful industrially, particularly for omega-3 concentration. Further selectivity modification would be useful and may be possible using targeted immobilisation strategies, although further work is required to develop these.

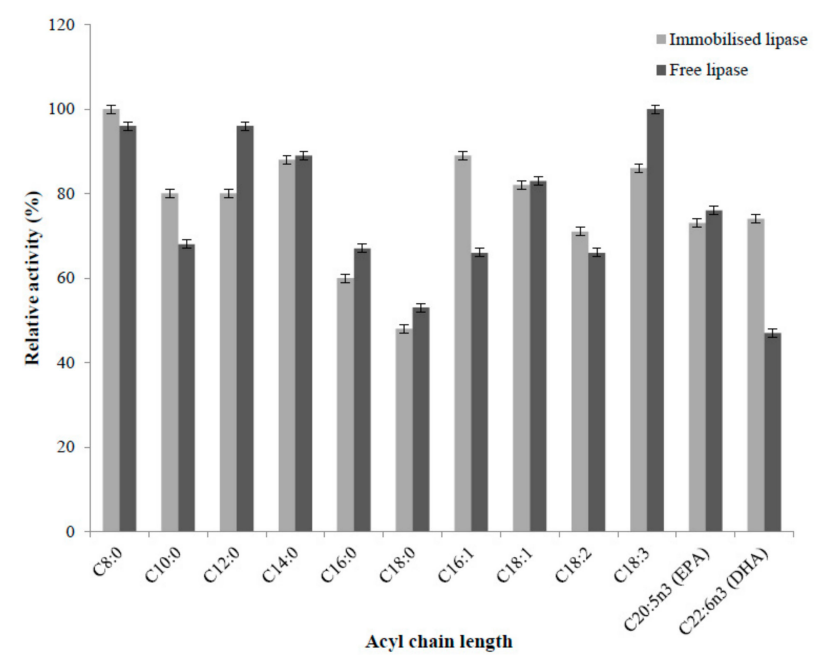

Figure 5. Effects of substrate specificity on free and immobilised lipase. The values are given as the mean of three experiments \pm standard deviation. 


\subsection{Fish Oil Hydrolysis of Immobilised and Free Enzyme}

Immobilised and free lipase was used for anchovy fish oil hydrolysis. TLC plate shows the separation of products, free fatty acid, triacylglycerol and diacylglycerol (Supplementary Figure S3). Immobilised and free enzymes were slow at fish oil hydrolysis (Table 3). The efficiency of fish oil hydrolysis is quite low (5\%) even after a relatively long period of incubation. This robust lipase was more effective with esters then with triacylglycerols.

Table 3. Fish oil hydrolysis by immobilised and free lipase. All experiments in this study were carried out in duplicate with standard deviation below 5\%. EPA: eicosapentaenoic acid; DHA: docosahexaenoic acid.

\begin{tabular}{cccc}
\hline Fatty Acid & Native Anchovy Oil Composition (\%) & Free Lipase & Immobilised Lipase \\
\hline Myristic acid (C14:0) & 8.34 & 5.49 & 7.09 \\
Palmitic acid (C16:0) & 16.69 & 11.82 & 14.97 \\
Palmitoleic acid (C16:1n7) & 9.78 & 9.16 & 9.32 \\
Oleic acid (C18:1n9) & 7.12 & 5.56 & 7.11 \\
EPA (C20:5n3) & 16.97 & 21.63 & 20.15 \\
DHA (C22:6n3) & 13.01 & 17.01 & 12.38 \\
\hline
\end{tabular}

Recently, cyanogen bromide agarose immobilised Candida rugosa lipase (CRL) rendered the lower fish oil hydrolysis after a long period of $96 \mathrm{~h}$, that was 1.1-fold more as compared to free enzyme [35]. Lipase sourced from T. lanuginosus (TL 100) in the free form was shown to have high selectivity for anchovy fish oil hydrolysis [36]. Lipase B from Candida antarctica in immobilised form using macroscale material was used to produce high omega-3 concentrate [6].

\section{Materials and Methods}

\subsection{Materials}

Recombinant lipase 6B sourced from Bacillus subtilis was produced and purified in our laboratory as per our previous optimised protocol [37]. Unsaturated long chain PUFA ( $p$ NP-Palmitoleic acid, C16:1n7; $p$ NP-oleic acid C18:1n9; $p$ NP- $\alpha$ linolenic acid C18:3n3; $p$ NP-linoleic acid C18:2n6; $p$ NP-EPA C20:5n3; $p$ NP-DHA C22:6n3) were synthesised as per our optimised protocol [38]. A protein assay kit and Tris-buffer were procured from Bio-Rad. Synthetic substrates ( $p$-nitrophenyl caprylate C8:0, p-nitrophenyl caprate C10:0, $p$-nitrophenyl laurate C12:0, $p$-nitrophenyl myristate C14:0, $p$-nitrophenyl palmitate C16:0; $p$-nitrophenyl sterate C18:0, gum acacia, Triton-X-100, $p$-nitrophenol, and gas liquid chromatography standards, were purchased from Sigma-Aldrich Chemical Co., Australia. Thin layer chromatography standards were purchased from Nu-Chek Prep (Elysian, MN, USA). Glutaraldehyde was procured from SAFC supply solution. Ferric chloride, ferrous chloride and sodium hydroxide were purchased from Ajax fine chemicals. Anchovy fish oil was provided by Ocean Nutrition Canada. Deionised double-distilled water (resistance value $\geq 18.2 \mathrm{M} \Omega \mathrm{cm}$ ) was used throughout the experiments. All analytical grade chemicals were used as received without any further purification.

\subsection{Synthesis and Characterisation of Zinc Doped Magnetic Iron Oxide Nanoparticles}

Chemical synthesis of zinc doped magnetic nanoparticles was carried out by mixing an equimolar ratio of ferric chloride, ferrous chloride and zinc chloride [39]. Black precipitates of magnetic nanoparticles were produced with the dropwise addition of one molar sodium hydroxide solution. The resulted nanoparticles were autoclaved followed by extensive washing with deionised water and finally freeze dried at $-80^{\circ} \mathrm{C}$ for $24 \mathrm{~h}$. The crystal structure and magnetisation versus applied magnetic field (M-H curves) of the nanoparticles was done by X-ray diffractometer (Pan Analytical, Almelo, The Netherlands) and semiconductor quantum interference device (SQUID) magnetometer (Quantum Design Inc, San Diego, CA, USA), respectively. 


\subsection{Immobilisation of Recombinant Lipase on Functionalised Magnetic Nanoparticles}

Surface chemistry of zinc doped functionalised nanoparticle and enzyme was exploited to develop nanoparticle bound lipase by covalent bonding between the carbonyl group of zinc doped magnetic nanoparticle and the amino group of the enzyme (Supplementary Figure S1). The magnetic nanoparticles $(5 \mathrm{mg} / \mathrm{mL}$ ) suspension in aqueous buffer ( $50 \mathrm{mM}$ Tris Buffer, $\mathrm{pH}$ 8.5) were first sonicated for $10 \mathrm{~min}$ followed by treated with one molar glutaraldehyde solution for $1 \mathrm{~h}$ at $25^{\circ} \mathrm{C}$ under constant stirring of $250 \mathrm{rpm}$ in a shaker [12]. Thereafter, excessive glutaraldehyde from magnetic nanoparticles suspension was removed by extensive washing with deionised water. Subsequent activated zinc doped magnetic nanoparticles $(5 \mathrm{mg} / \mathrm{mL})$ were mixed with the purified enzyme of different concentrations (5-20 mg in $50 \mathrm{mM}$ Tris buffer, $\mathrm{pH}$ 8.5) to optimise the enzyme-loading ratio on the surface of nanoparticle at $25^{\circ} \mathrm{C}$ in a shaker ( $150 \mathrm{rpm}$ ) for $12 \mathrm{~h}$. Removal of non-covalently bound enzyme onto the surface of magnetic nanoparticles was done via washing with one molar solution of sodium chloride until no enzyme leakage was reported in the washings.

The biocatalytic potential of nanoparticle bound enzyme in terms of immobilisation efficiency and immobilisation yield were evaluated as per the earlier optimised study [17]. The amount of immobilised lipase was determined to be $0.6 \mathrm{mg}$ protein/mg zinc doped magnetic nanoparticle at equal ratio of protein and nanoparticle (in $\mathrm{mg}$ ). Biocatalytic potential of the nanoparticle bound lipase was $70 \%$ than the free lipase. Bradford method was done for evaluating the protein content by using Bio-Rad protein dye reagent concentrate and bovine serum albumin as a standard protein [40]. The washed magnetic nanoparticle was directly used for optimising all other experimental parameters.

\subsection{Biophysical Characterisation of Zinc Doped Nanoparticle Immobilised Enzyme}

The morphology of free and enzyme bound nanoparticles was studied by TEM using a JEOL 2100M microscope (Frenchs forest, NSW, Australia). Sample preparations were done by drying a drop of aqueous zinc doped magnetic nanoparticle dispersion on the carbon-coated specimen grid at room temperature and subsequent the imaging of TEM sample was captured. Negative staining was performed using electron dense material, phosphotungstic acid.

The FTIR analysis of magnetic nanoparticle immobilised lipase and free lipase was carried out by using an Alpha FTIR spectrometer (Bruker Optik GmbH, Ettlingen, Germany) to confirm the enzyme coating on the surface of zinc doped magnetic nanoparticles. The ATR-FTIR spectra to each sample measurement were acquired as per the previous study [13].

Circular dichroism (CD) spectroscopy was done to track the secondary structural changes in free enzyme after the covalent binding on the surface of the zinc doped magnetic nanoparticles. The UV CD spectra were recorded in the range of $200-260 \mathrm{~nm}$ by using a JASCO J-810 CD instrument (JASCO). An equal enzyme concentration of $50 \mu \mathrm{g} / \mathrm{mL}$ was used in all CD measurement studies at $25^{\circ} \mathrm{C}$ in diluted buffer (10 mM Tris, $\mathrm{pH} 8.5$ ) as per the previous published study [13].

\subsection{Determination of Immobilised Enzyme Activity and Protein Concentration}

The colorimetric assay was performed to measure the enzyme activity of free and zinc doped magnetic nanoparticle immobilised enzyme at $410 \mathrm{~nm}$ [41]. The reaction mixture \{substrate $p$-nitrophenol palmitate ( $p$-NPP solution $(3 \mathrm{mg} / \mathrm{mL})$, enzyme, Tris buffer $(50 \mathrm{mM}, \mathrm{pH} 8.5), 0.4 \%$ $(w / v)$ Triton-X-100 and $0.1 \%(w / v)$ gum acacia\} was incubated at $65^{\circ} \mathrm{C}$ for $10 \mathrm{~min}$ in a shaking water bath. The enzyme reaction was terminated by enzyme inactivation at $-20^{\circ} \mathrm{C}$ for $10 \mathrm{~min}$. The absorbance of para-nitrophenol product was recorded by UV-Vis Spectrophotometer (Shimadzu, Japan) at $410 \mathrm{~nm}$. One unit of enzyme activity is defined as $1 \mu \mathrm{mol}$ of $p$-nitrophenol liberated per minute under standard assay condition. Enzyme assay of ten microgram of immobilised lipase was performed with $p$ NPP and compared with an equal amount corresponding to free enzyme using standard assay condition. All enzyme assays of free and magnetic nanoparticle immobilised enzymes were performed in triplicate and reported as mean values $\pm \mathrm{SD}$. 


\subsection{Biochemical Characterisation of the Zinc Doped Magnetic Nanoparticle Immobilised and Free Lipase}

\subsubsection{Effect of $\mathrm{pH}$ on the Enzyme Activity of Immobilised and Free Lipase}

The effect of $\mathrm{pH}$ on the activity of the free and immobilised lipase was determined by using different Tris buffer $\mathrm{pH}(\mathrm{pH} 7.0-9.5,50 \mathrm{mM})$ at $65^{\circ} \mathrm{C}$. The optimal activity for the immobilised and free lipase was reported at $\mathrm{pH} 8.5$ and defined as control, representing $100 \%$ relative activity, to evaluate other relative activity at different $\mathrm{pH}$ and expressed as fractions thereof.

\subsubsection{Optimum Temperature and Thermal Stability}

The effect of temperature on the activity of free and immobilised enzyme was investigated over the range of $25-95{ }^{\circ} \mathrm{C}$. The optimum temperature at $65^{\circ} \mathrm{C}$ was reported at optimised pH 8.5 and defined as control, representing $100 \%$ relative activity, to evaluate other relative activity at different temperature and expressed as fractions thereof.

The lipase (immobilised and free form) was evaluated for thermal stability at selected high temperature of $85^{\circ} \mathrm{C}$ for a regular time interval using standard assay. The relative activity of the lipase (immobilised and free form) without incubation was defined as control, representing 100\% residual activity for different intervals of the heat treatment for evaluating the respective activities.

\subsubsection{Reusability of the Zinc Doped Magnetic Nanoparticle Immobilised Lipase}

The reusability of the immobilised enzyme was determined under standard assay conditions. After each cycle of hydrolysis, the magnetic nanoparticle immobilised enzyme was separated by using a magnet followed by washing with deionised water and assay buffer, then resuspended in the fresh assay buffer under standard assay conditions. The residual activity (\%) in the first cycle was taken as $100 \%$.

\subsubsection{Determination of Enzyme Kinetics}

To determine the enzyme kinetics, the immobilised and free lipase were treated with different substrate concentrations ( $p$-NPP; $5-40 \mathrm{mM}$ ) under standard assay conditions. The kinetic parameters, $K_{M}$ and $V_{\max }$ values, of magnetic nanoparticle immobilised and free lipases were evaluated by non-linear regression fitting of the Michaelis-Menten equation using Prism 6 (Graphpad Software Inc., San Diego, CA, USA).

\subsubsection{Substrate Specificity for Long Chain Polyunsaturated Fatty Acids (PUFAs)}

The substrate specificity of immobilised and free lipase was determined using $p$ NP esters with different carbon chain length ranging from C8 to C22 with different degree of unsaturation. Substrate stock $(8 \mathrm{mM})$ was prepared in isopropanol. The lipase was incubated with each substrate ranging from C8-C22 prepared in Tris buffer ( $50 \mathrm{mM}$, pH 8.5) for $10 \mathrm{~min}$ at $65^{\circ} \mathrm{C}$ under shaking. The released $p$ NP from the substrates $p$-nitrophenyl caprylate C8:0, $p$-nitrophenyl caprate C10:0, $p$-nitrophenyl laurate $\mathrm{C} 12: 0$, $p$-nitrophenyl myristate $\mathrm{C} 14: 0$, $p$-nitrophenyl palmitate $\mathrm{C} 16: 0$; $p$-nitrophenyl sterate C18:0; $p$ NP-Palmitoleic acid, c16:1n7; $p$ NP-oleic acid C18:1n9; $p$ NP- $\alpha$ linolenic acid C18:3n3; $p$ NP-linoleic acid C18:2n6; $p$ NP-EPA C20:5n3; $p$ NP-DHA C22:6n3 was evaluated using a standard colorimetric assay.

\subsection{Fish Oil Hydrolysis Using Immobilised and Free Lipase}

\subsubsection{Analysis of Lipid Classes by Thin Layer Chromatography}

Silica gel TLC plate was used to analyse the lipid fractions. Lipid fractions $(1 \mu \mathrm{L})$ prepared in hexane were spotted on the line of origin and run for $30 \mathrm{~min}$ in a solvent tank comprising three solvents of different ratios i.e., hexane/diethyl ether/acetic acid (60:40:1, v/v \%) at room temperature. Iodine stain sprayed with pipette to visualise the product(s) separation. 


\subsubsection{Analysis of Lipid Classes by Capillary Chromatography (Iatroscan) and Gas Chromatography}

The capillary chromatography was employed to analyse the hydrolysed as well as unhydrolysed portions of the fish oil by immobilised and free lipase (flame ionisation detector (FID); Iatroscan MK5, Iatron Laboratories Inc., Tokyo, Japan). The Iatroscan were run with $30 \mathrm{~s}$ per scan speed by keeping air and hydrogen flow rate of $200 \mathrm{~mL} / \mathrm{min}$ and $160 \mathrm{~mL} / \mathrm{min}$ respectively. The chromarods were cleaned prior to applying samples and scanned twice as per the above specified conditions. Lipid fraction of each hydrolysed and unhydrolysed fish oil samples $(1 \mu \mathrm{L})$ were spotted onto the rods and developed in a solvent buffer for $22 \mathrm{~min}$ and compared with TLC standards to identify each lipid class.

Firstly, the hydrolysed and unhydrolysed anchovy fish oil fractions by immobilised and free lipase were converted to methyl esters with slight modifications of previous method [42]. Anchovy oil (10 mg) was dissolved in toluene $(1 \mathrm{~mL})$, followed by addition of internal standard $(200 \mu \mathrm{L}, 5 \mathrm{mg} / \mathrm{mL}$ methyl nonadecanoate) and antioxidant $(200 \mu \mathrm{L} ; 1 \mathrm{mg} / \mathrm{mL} ; 2,6$-di-tert-butyl-4-methylphenol (butylated hydroxytoluene). Two millilitre of hydrogen chloride in methanol was mixed and incubated at $50{ }^{\circ} \mathrm{C}$ for $12 \mathrm{~h}$ followed by addition of sodium chloride solution $(5 \mathrm{~mL}, 5 \% \mathrm{w} / \mathrm{v})$. Hexane was used to extract the corresponding fatty acid methyl esters. Hexane was removed from the methyl esters by treating with potassium bicarbonate solution $(5 \mathrm{~mL} ; 2 \% w / v)$ and sodium sulphate followed by rotary evaporation.

Gas chromatography was used to analysed immobilised and free enzyme treated fish oil samples (Agilent 6890 gas chromatograph, FID detector, Supelcowax 10 capillary column of $30 \mathrm{~m}$ long with $0.25 \mathrm{~mm}$ internal diameter). Gas chromatography programming was set by keeping the oven temperature from $140{ }^{\circ} \mathrm{C}$ to $240^{\circ} \mathrm{C}$ with each 5-min hold at a rate of $4{ }^{\circ} \mathrm{C} / \mathrm{min}$ and injector temperature of $250^{\circ} \mathrm{C}$. One microliter of the lipid fraction sample was injected with a split ratio of 50:1 while keeping the flow rate of helium carrier gas and detector gases was $1.5 \mathrm{~mL} / \mathrm{min}$, and $30 \mathrm{~mL} / \mathrm{min}$ hydrogen, $300 \mathrm{~mL} / \mathrm{min}$ air, $30 \mathrm{~mL} / \mathrm{min}$ nitrogen, respectively. Results of corresponding peak areas were analysed by ChemStation software and theoretical FID response factors [43].

\section{Conclusions}

Bacillus subtilis lipase is a heat stable enzyme with a wide substrate spectrum. Recombinant lipase was immobilised on magnetic nanoparticle by a facile covalent method. High loading of enzyme to the functionalised nanoparticle was achieved with protein binding efficiency of $95 \%$. A post-immobilisation structural change of enzyme on the nanocarrier was investigated using TEM, ATR-FTIR spectroscopy and CD spectroscopy techniques. The immobilised and free lipase was biochemically characterised by assessing the effect of enzyme activities as a function of different reaction parameters like $\mathrm{pH}$, temperature, substrates concentration and specificity reaction conditions. Reusability of the immobilised enzyme was investigated using a $p$ NPP hydrolysis model and the enzyme showed more than $80 \%$ residual activity up 11 cycles, with improved thermal stability. The immobilised enzyme showed 1.5 times higher selectivity for DHA, while retaining almost the same degree of selectivity for EPA than the free enzyme.

Design and application of a robust magnetic nanoparticle immobilised lipase towards fish oil hydrolysis has practical application for enriching triglycerides with PUFAs, in particular to EPA and DHA. Magnetic hybrid composite produced through the surface modification of magnetic nanoparticle with suitable moieties such as graphene oxide, silica, aminopropyl-functionalised hydroxyapatite, poly (styrene-methacrylic acid) provides an excellent support for lipase immobilisation for the application of EPA and DHA concentration in fish oil triacylglycerides.

Supplementary Materials: The following are available online at http://www.mdpi.com/2073-4344/9/5/420/s1, Figure S1: Immobilisation of a recombinant lipase on a functionalised magnetic nanoparticle (NP) by covalent method. Figure S2: Immobilisation study of protein binding on functionalised magnetic nanoparticles. Figure S3: TLC separation of anchovy oil hydrolysis products of immobilised and free lipase. Figure S4: Magnetic hysteresis curve of undoped nanoparticles. 
Author Contributions: Conceived and designed the experiments: M.P. and M.L.V.; Performed the experiments: M.L.V. Analysed the data: M.L.V. and M.P.; Contributed reagents/materials/analysis tools: M.L.V., N.M.R., T.T., C.J.B. and M.P.; Wrote the paper: M.L.V. and M.P.

Funding: Authors are thankful to the strategic research funding (Australian-India research grant) to Deakin University, Australia (Centre for Chemistry and Biotechnology) for providing funding to pursue research. Research funding in the form of Alfred Deakin Post-Doctoral fellowship (Project ID\#RM24013) to one of the authors (M. Verma) is thankfully acknowledged. The funders had no role in study design, data collection and analysis, decision to publish, or preparation of the manuscript.

Acknowledgments: Authors are thankful to R. Chaudhary, T. Aknabi and T. Nalder for providing the some reagents used in the present study.

Conflicts of Interest: The authors declare no conflict of interest.

\section{References}

1. Porta, R.; Pandey, A.; Rosell, C.M. Enzymes as additives or processing aids in food biotechnology. Enzym. Res. 2010, 2010, 436859. [CrossRef]

2. Kim, H.; Choi, N.; Oh, S.W.; Kim, Y.; Kim, B.H.; Kim, I.H. Synthesis of $\alpha$-linolenic acid-rich triacylglycerol using a newly prepared immobilized lipase. Food Chem. 2017, 237, 654-658. [CrossRef]

3. Xie, W.; Zang, X. Covalent immobilization of lipase onto aminopropyl-functionalized hydroxyapatite-encapsulated- $\gamma-\mathrm{Fe}_{2} \mathrm{O}_{3}$ nanoparticles: A magnetic biocatalyst for interesterification of soybean oil. Food Chem. 2017, 227, 397-403. [CrossRef]

4. Xie, W.; Zang, X. Lipase immobilized on ionic liquid-functionalized magnetic silica composites as a magnetic biocatalyst for production of trans-free plastic fats. Food Chem. 2018, 257, 15-22. [CrossRef] [PubMed]

5. Ferreira-Dias, S.; Sandoval, G.; Plou, F.; Valero, F. The potential use of lipases in the production of fatty acid derivatives for the food and nutraceutical industries. Electron. J. Biotechnol. 2013, 16, 3.

6. Kanwar, S.S.; Verma, M.L. Lipases. In Encyclopedia of Industrial Biotechnology: Bioprocess, Bioseparation, and Cell Technology; Wiley: Hoboken, NJ, USA, 2010; pp. 1-16.

7. Fernandez-Lafuente, R. Lipase from Thermomyces lanuginosus: Uses and prospects as an industrial biocatalyst. J. Mol. Catal. B Enzym. 2010, 62, 197-213. [CrossRef]

8. Kralovec, J.A.; Zhang, S.; Zhang, W.; Barrow, C.J. A review of the progress in enzymatic concentration and microencapsulation of omega-3 rich oil from fish and microbial source. Food Chem. 2012, 131, 639-644. [CrossRef]

9. Xie, W.; Huang, J. Immobilization of Candida rugosa lipase onto graphene oxide $\mathrm{Fe}_{3} \mathrm{O}_{4}$ nanocomposite: Characterization and application for biodiesel production. Energy Convers. Manag. 2018, 159, 42-53. [CrossRef]

10. Mateo, C.; Palomo, J.M.; Fernandez-Lorente, G.; Guisan, J.M.; Fernandez-Lafuente, R. Improvement of enzyme activity, stability and selectivity via immobilization techniques. Enzym. Microb. Technol. 2007, 40, 1451-1463. [CrossRef]

11. Xie, W.; Wang, J. Enzymatic production of biodiesel from soybean oil by using immobilized lipase on $\mathrm{Fe}_{3} \mathrm{O}_{4} /$ poly(styrene-methacrylic acid) magnetic microsphere as a biocatalyst. Energy Fuels 2014, 28, 2624-2631. [CrossRef]

12. Verma, M.L.; Chaudhary, R.; Tsuzuki, T.; Barrow, C.J.; Puri, M. Immobilization of $\beta$-glucosidase on magnetic nanoparticle improves thermostability: Application in cellobiose hydrolysis. Bioresour. Technol. 2013, 135, 2-6. [CrossRef] [PubMed]

13. Verma, M.L.; Naebe, M.; Barrow, C.J.; Puri, M. Enzyme immobilisation on amino-functionalised multi-walled carbon nanotubes: Structural and biocatalytic characterisation. PLoS ONE 2013, 8, e73642. [CrossRef]

14. Xie, W.; Zang, X. Immobilized lipase on core-shell structured $\mathrm{Fe}_{3} \mathrm{O}_{4}-\mathrm{MCM}-41$ nanocomposites as a magnetically recyclable biocatalyst for interesterification of soybean oil and lard. Food Chem. 2016, 194, 1283-1292. [CrossRef] [PubMed]

15. Kim, J.; Grate, J.W.; Wang, P. Nanobiocatalysis and its potential applications. Trends Biotechnol. 2008, 26, 639-646. [CrossRef] [PubMed]

16. Ansari, S.A.; Husain, Q. Potential applications of enzymes immobilized on/in nanomaterials: A review. Biotechnol. Adv. 2012, 30, 512-523. [CrossRef] 
17. Verma, M.L.; Barrow, C.J.; Kennedy, J.F.; Puri, M. Immobilization of $\beta$-galactosidase from Kluyveromyces lactis on functionalized silicon dioxide nanoparticles: Characterization and lactose hydrolysis. Int. J. Biol. Macromol. 2012, 50, 432-437. [CrossRef]

18. Singh, N.; Srivatava, G.; Talat, M.; Raghubanshi, H.; Srivastava, O.N.; Kayastha, A.M. Cicer $\alpha$-galactosidase immobilization onto functionalized grapheme nanosheets using response surface methods and its applications. Food Chem. 2014, 142, 430-438. [CrossRef]

19. Cao, M.; Li, Z.; Wang, J.; Ge, W.; Yue, T.; Li, R.; Colvin, V.L.; Yu, W.W. Food related applications of magnetic iron oxide nanoparticles: Enzyme immobilization, protein purification, and food analysis. Trends Food Sci. Technol. 2012, 27, 47-56. [CrossRef]

20. Pavlidis, I.V.; Vorhaben, T.; Tsoufis, T.; Rudolf, P.; Bornscheuer, U.T.; Gournis, D.; Stamatis, H. Development of effective nanobiocatalytic systems through the immobilisation of hydrolases on functionalized carbon-based nanomaterials. Bioresour. Technol. 2012, 115, 164-171. [CrossRef]

21. Hu, B.; Pan, J.; Yu, H.; Liu, J.; Xu, J. Immobilisation of Serratia marcescens lipase onto amino-functionalised magnetic nanoparticles for repeated use in enzymatic synthesis of Diltiazem intermediate. Process Biochem. 2009, 44, 1019-1024. [CrossRef]

22. Koh, A.L.; Sinclair, R. TEM observations of bio-conjugated streptavidin-gold nanoparticles. MRS Proc. 2007, 1019. [CrossRef]

23. Manning, M.C. Use of infrared spectroscopy to monitor protein structure and stability. Expert Rev. Proteom. 2005, 2, 731-743. [CrossRef] [PubMed]

24. Bruce, I.J.; Sen, T. Surface modification of magnetic nanoparticles with alkoxysilanes and their application in magnetic bioseparations. Langmuir 2005, 21, 7029-7035. [CrossRef]

25. Ganesan, A.; Moore, B.D.; Kelly, S.M.; Price, N.C.; Rolinski, O.J.; Birch, D.J.S.; Dunkin, I.R.; Halling, P.J. Optical spectroscopic methods for probing the conformational stability of immobilised enzymes. ChemPhysChem 2009, 10, 1492-1499. [CrossRef]

26. Talbert, J.N.; Goddard, J.M. Characterization of lactase-conjugated magnetic nanoparticles. Process Biochem. 2013, 48, 656-662. [CrossRef]

27. Jiang, Y.; Guo, C.; Xia, H.; Mahmood, I.; Liu, C.; Liu, H. Magnetic nanoparticles supported ionic liquids for lipase immobilization: Enzyme activity in catalysing esterification. J. Mol. Catal. B Enzym. 2009, 58, $103-109$. [CrossRef]

28. Xia, G.H.; Liu, W.; Jaing, X.P.; Wang, X.Y.; Zhang, Y.W.; Guo, J. Surface modification of $\mathrm{Fe}_{3} \mathrm{O}_{4} @ \mathrm{SiO}_{2}$ magnetic nanoparticles for immobilization of lipase. J. Nanosci. Nanotechnol. 2017, 17, 370-376. [CrossRef]

29. Hanefeld, U.; Gardossi, L.; Magner, E. Understanding enzyme immobilisation. Chem. Soc. Rev. 2009, 38, 453-468. [CrossRef]

30. Matuoog, N.; Li, K.; Yan, Y. Thermomyces lanuginosus lipase immobilized on magnetic nanoparticles and its application in the hydrolysis of fish oil. J. Food Biochem. 2018, 42, e12549. [CrossRef]

31. Sorensen, M.H.; Ng, J.B.S.; Bergstrom, L.; Alberius, P.C.A. Improved enzymative activity of Thermomyces lanuginosus lipase immobilized in a hydrophilic particulate mesoporous carrier. J. Colloid Interface Sci. 2010, 343, 359-365. [CrossRef]

32. Karabulut, I.; Durmaz, G.; Hayaloglu, A. Fatty acid selectivity of lipases during acidolysis reaction between triolein and saturated fatty acids varying from caproic and behenic acids. J. Agric. Food Chem. 2009, 57, 7584-7590. [CrossRef]

33. Matuoog, N.; Li, K.; Yan, Y. Immobilization of Thermomyces lanuginosus lipase on multi-walled carbon nanotubes and its application in the hydrolysis of fish oil. Mat. Res. Express 2017, 4, 25402. [CrossRef]

34. Urrutia, P.; Arrieta, R.; Alvarez, L.; Cardenas, C.; Mesa, M.; Wilson, L. Immobilization of lipases in hydrophobic chitosan for selective hydrolysis of fish oil: The impact of support functionalization on lipase activity, selectivity and stability. Int. J. Biol Macromol. 2018, 108, 674-686. [CrossRef]

35. Junior, W.G.M.; Fernandez-Lorente, G.; Guisan, J.M.; Ribeiro, E.J.; Resende, M.M.D. Production of omega-3 polyunsaturated fatty acids through hydrolysis of fish oil by Candida rugosa lipase immobilized and stabilized on different supports. Biocatal. Biotransform. 2017, 35, 63-73. [CrossRef]

36. Aknabi, A.O.; Adcock, J.A.; Barrow, C.J. Selective concentration of EPA and DHA using Thermomyces lanuginosus lipase is due to fatty acid selectivity and not regioselectivity. Food Chem. 2013, 138, 615-620. [CrossRef] 
37. Ahmad, S.; Kamal, M.Z.; Sankaranarayanan, R.; Rao, N.M. Thermostable Bacillus subtilis lipases: In vitro evolution and structural insight. J. Mol. Biol. 2008, 381, 324-340. [CrossRef] [PubMed]

38. Nalder, T.D.; Marshall, S.; Pfeffer, F.M.; Barrow, C.J. Characterisation of lipase fatty acid selectivity using novel omega-3 $p$ NP-acyl esters. J. Funct. Foods 2014, 6, 259-269. [CrossRef]

39. Chaudhary, R.; Roy, K.; Kanwar, R.K.; Walder, K.; Kanwar, J.R. Engineered atherosclerosis-specific zinc ferrite nanocomplexes-based MRI contrast agents. J. Biotechnol. 2016, 14, 6.

40. Bradford, M.M. A rapid and sensitive method for the quantitation of microgram quantities of protein utilizing the principle of protein-dye binding. Anal. Biochem. 1976, 72, 248-254. [CrossRef]

41. Winkler, U.K.; Stuckmann, M. Glucogen hyaluronate and some other polysaccharides greatly enhance the formation of exolipase by Serratia marcescens. J. Bacteriol. 1979, 138, 663-670. [PubMed]

42. Christie, W.W.; Han, X. Lipid Analysis: Isolation, Separation, Identification and Lipidomic Analysis, 4th ed.; Oily Press, PJ Barnes \& Associates: Bridgwater, UK, 2010.

43. Craske, J.D.; Babbon, C.D. Gas liquid chromatography analysis of the fatty acid composition of fats and oils: A total system for high accuracy. J. Am. Oil Chem. Soc. 1987, 64, 1413-1417. [CrossRef]

(C) 2019 by the authors. Licensee MDPI, Basel, Switzerland. This article is an open access article distributed under the terms and conditions of the Creative Commons Attribution (CC BY) license (http://creativecommons.org/licenses/by/4.0/). 